\title{
Synovial sarcoma of the hand-wrist: a case report and review of the literature
}

\author{
Serenella Serinelli, , Lorenzo Gitto and Daniel J. Zaccarini
}

\begin{abstract}
Background: Synovial sarcomas are infrequent malignant tumors occurring mostly in adolescents and young adults. The occurrence of synovial sarcoma in the hand-wrist area is rare (4 to 8.5\% of all synovial sarcomas in different studies).

Case presentation: This report documents an uncommon case of synovial sarcoma occurring in the hand-wrist of a 69 -year-old Caucasian woman. She was subsequently treated with surgical excision and radiotherapy without recurrence after follow up.

Conclusions: This paper aims to characterize the demographic, pathologic, and clinical features with a literature review. The present literature review confirms that hand-wrist synovial sarcomas are more frequent among males and subjects 10 to 40 years old. Most cases in this location are usually not larger than $5 \mathrm{~cm}$ in size. The five-year survival rate is higher than that reported in a previous review on hand synovial sarcomas, and this suggests an improved survival in recent decades.
\end{abstract}

Keywords: Synovial sarcoma, Hand, Wrist, Survival, Case report

\section{Background}

Synovial sarcomas are malignant neoplasms with mesenchymal and variable epithelial differentiation. They are infrequent, accounting for $5-10 \%$ of all soft tissue sarcomas [1]. For every one million people in the United States, one to two are diagnosed with synovial sarcoma each year [2]. This tumor is most common in adolescents and young adults; with the majority of cases occurring between 10 and 40 years of age $[1,3]$. It is rarely encountered in those over 50 years old. There is a slight male preponderance [3], and similar incidences in all ethnic groups have been described $[4,5]$. This neoplasm can occur in almost any location in the body. In the vast majority of cases, it involves deep soft tissue of the lower extremities, frequently in the vicinity of large joints, like the knee and ankle [6]. It can also occur in viscera (heart, lung, pleura, kidney), oral cavity, mediastinum, retroperitoneum, peritoneum, central nervous system, and peripheral nerves. Typically, it has a slow growth pattern and benign radiologic appearance. Clinically, synovial sarcomas can be associated with pain depending on their location in relation to nerves. Some authors have observed that long-lasting pain at the tumor site before the development of swelling is more common with synovial sarcomas than with other sarcomas [7]. Most cases, however, are diagnosed only when their size is larger than $5 \mathrm{~cm}$ [8]. Similar to other soft tissue sarcomas, synovial sarcomas in the hand-wrist area are infrequent [9].

This paper documents an unusual case of hand-wrist synovial sarcoma in a 69-year-old Caucasian woman, and

*Correspondence: serinels@upstate.edu

Department of Pathology, State University of New York - Upstate Medical

University, 750 E. Adams St, Syracuse, NY 13210, USA

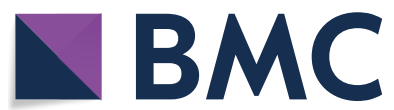

(c) The Author(s) 2021. Open Access This article is licensed under a Creative Commons Attribution 4.0 International License, which permits use, sharing, adaptation, distribution and reproduction in any medium or format, as long as you give appropriate credit to the original author(s) and the source, provide a link to the Creative Commons licence, and indicate if changes were made. The images or other third party material in this article are included in the article's Creative Commons licence, unless indicated otherwise in a credit line to the material. If material is not included in the article's Creative Commons licence and your intended use is not permitted by statutory regulation or exceeds the permitted use, you will need to obtain permission directly from the copyright holder. To view a copy of this licence, visit http://creativecommons.org/licenses/by/4.0/. The Creative Commons Public Domain Dedication waiver (http://creativeco mmons.org/publicdomain/zero/1.0/) applies to the data made available in this article, unless otherwise stated in a credit line to the data. 
characterizes this condition's demographic, pathologic, and clinical features with a literature review.

\section{Case presentation}

A 69-year-old Caucasian woman with a past medical history of low back pain, hypertension, and hyperlipidemia presented with a chief complaint of a dorsal ulnar-sided left hand-wrist mass that had been growing slowly over the previous 10 years. The patient stated that the mass had become progressively more painful over time, being particularly tender when she wore a watch. There had been no history of preceding trauma nor constitutional symptoms. On physical exam, the skin on the hands and wrist was intact with normal musculature. In the left dorsal ulnar wrist, near the extensor carpi ulnaris tendon, there was a small palpable mass that was semi-firm and not mobile; quite tender to palpation. A hand-wrist X-ray showed marked osteoarthritic changes. An initial clinical diagnosis of a probable ganglion cyst was made, and the patient underwent surgical excision of the mass.

The pathology of the soft tissue fragments revealed a biphasic neoplasm composed of spindle cells admixed with neoplastic glands (Fig. 1). No necrosis or active mitotic activity was seen. The tumor cells were positive for TLE1, focally positive for CK19, CK7, and S100, and negative for CDX2, SMA, CK20, and TTF-1 (Fig. 2). Due to tissue fragmentation, surgical margins could not be assessed; although they appeared to be involved by the neoplasm. FISH (fluorescence in situ hybridization) for SS18 (SYT) gene break-apart rearrangement on chromosome 18q11.2 was performed (Fig. 3), and the SYT gene rearrangement was detected in $71 \%$ of cells; thus confirming the diagnosis of synovial sarcoma.

CT (computed tomography) of the thorax/abdomen and pelvis were without evidence of metastatic sarcoma. The tumor was classified as AJCC (American Joint Commission on Cancer) Stage IIA. A wide re-excision of the tumor was performed with en-bloc resection of the distal ulna. The resected tissue showed an ill-defined $1.0 \times 0.5 \times 0.5 \mathrm{~cm}$ firm mass involving the soft tissue without involving the bone. The histopathologic exam confirmed the prior diagnosis. The patient received adjuvant radiotherapy and had regular follow-ups for 5.5 years with no evidence of any local

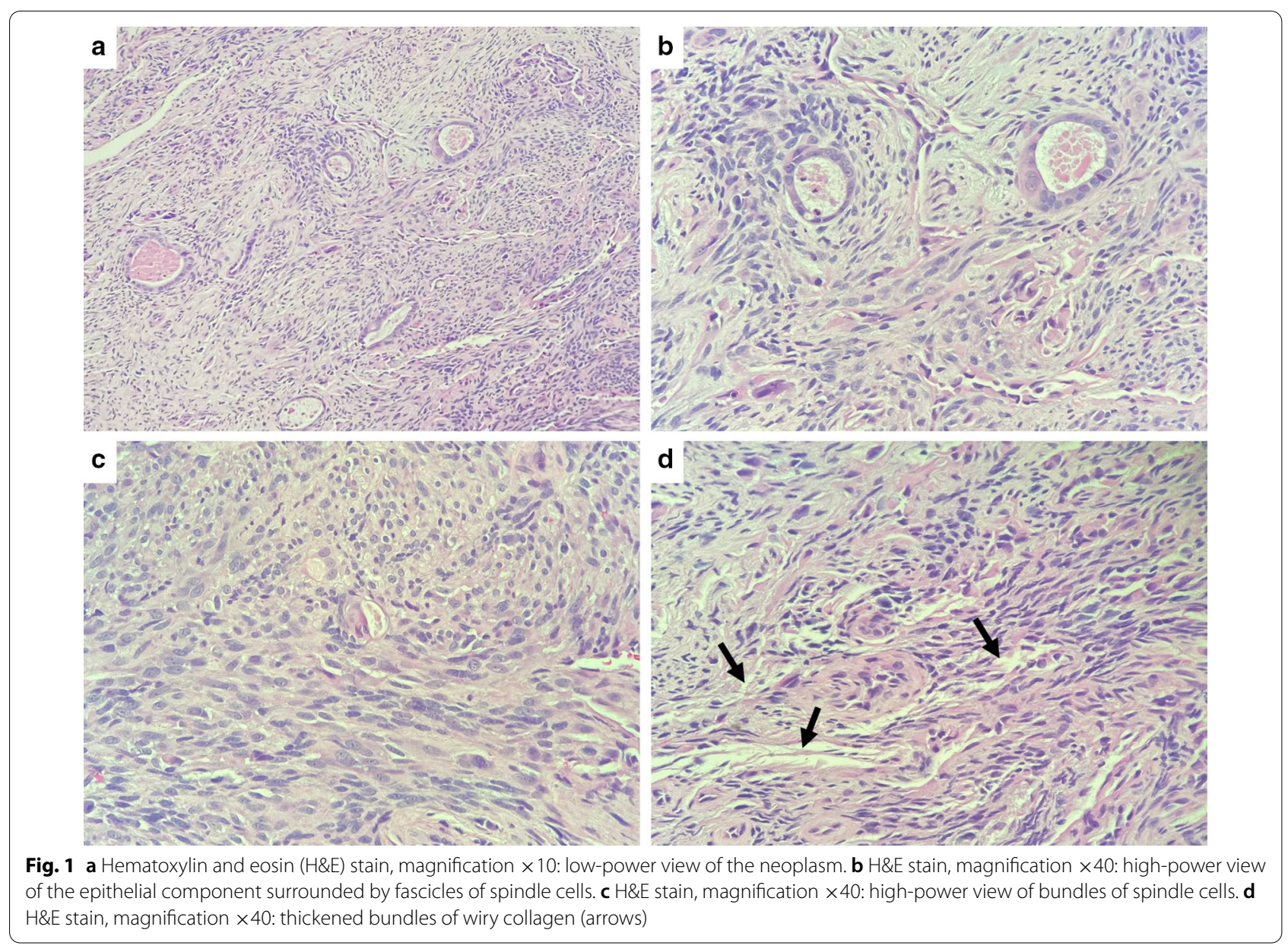



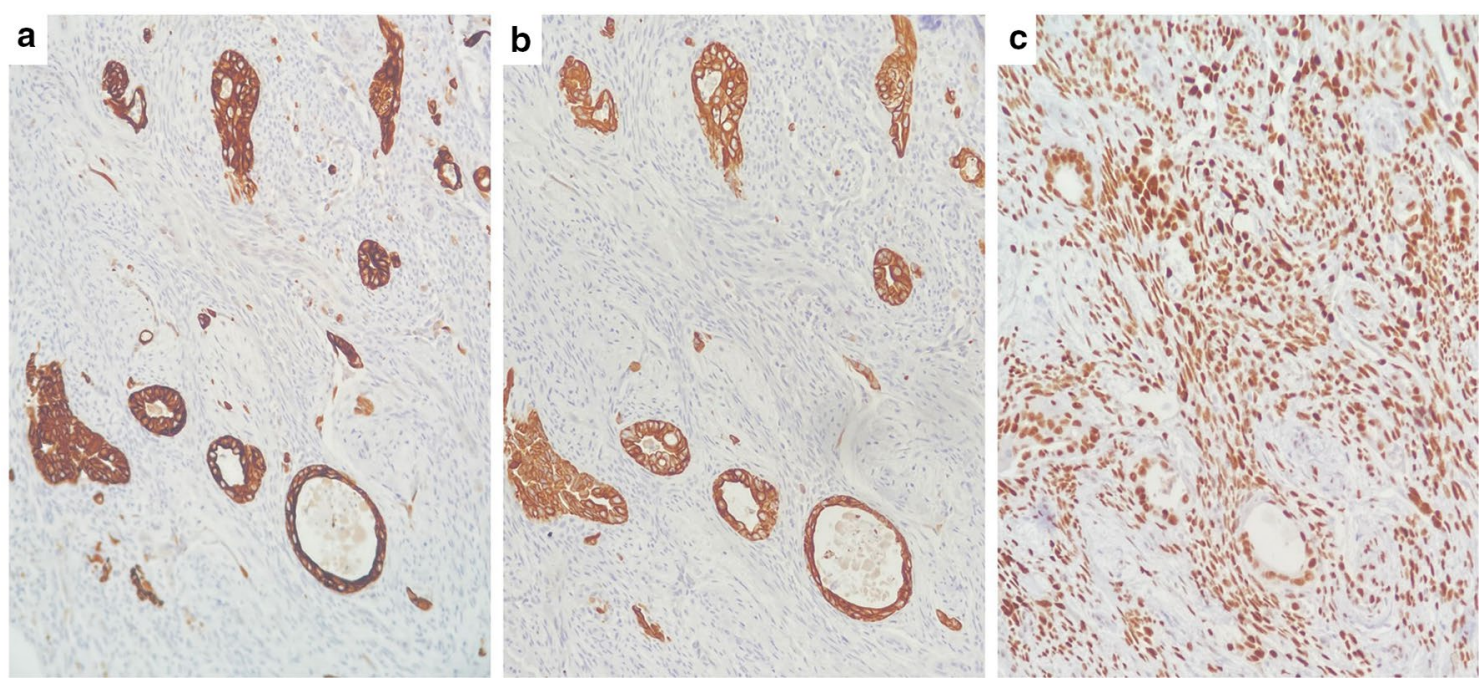

Fig. 2 a-c CK7 (a), CK19 (b), and TLE1 (c) stains, magnification $\times 20$ : strong expression of CK7 and CK19 in the epithelial component, with focal/ patchy expression in the spindled cells. The tumor cells are positive for TLE1

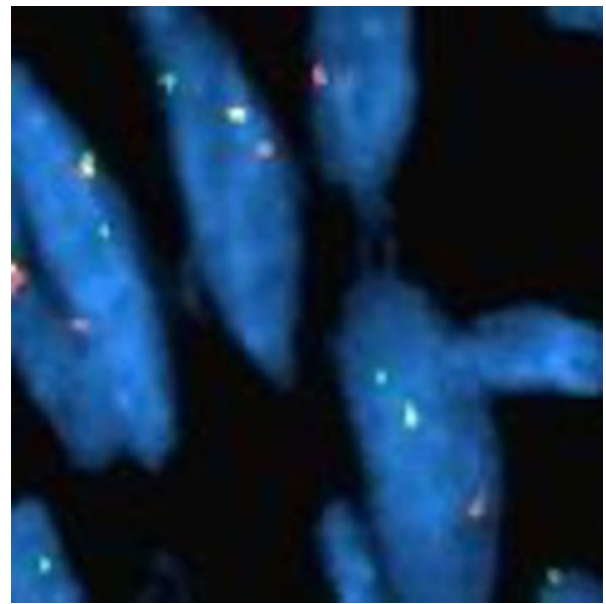

Fig. 3 Interphase FISH for the assessment of SS18 (SYT) gene break-apart rearrangement: the first probe, a SpectrumOrange labeled $\sim 650 \mathrm{~kb}$ probe, extends distally from the SS18 (SYT) gene. The second probe, a SpectrumGreen labeled $\sim 1040 \mathrm{~kb}$ probe, lies proximal to the SS18 (SYT) gene. In normal cells that lack SS18 (SYT) gene rearrangement, two pairs of orange and green fusion signals will be observed. In abnormal or tumor cells with SS18 (SYT) gene break-apart, one fusion, one green and one orange signal pattern are seen, as in the cells showed

recurrence of the tumor or distant metastases. The timeline of the episode of care is summarized in Fig. 4.

\section{Discussion and conclusions}

Synovial sarcomas are rarely encountered in routine clinical practice. Nevertheless, they are a highly malignant type of soft tissue sarcoma. Therefore, clinicians and pathologists should always maintain a high level of suspicion to ensure these cases are not unrecognized.

Synovial sarcomas in the hand-wrist area are an uncommon occurrence. Their frequency is $4-8.5 \%$ of all synovial sarcomas in different studies [10-12]. When a synovial sarcoma arises in the hand-wrist, the incidence of finger involvement is less common than that of the carpus $[4,13]$. Clinically, many of these tumors, particularly when small in size, are initially misinterpreted as benign lesions such as ganglion cysts or glomus tumors.

The synovial sarcoma case herein described is particularly unusual considering the patient's age and sex (a woman in her late sixties), and the infrequent location (the hand-wrist region). Despite its name, synovial sarcomas do not arise from synovium and rarely occur in the joints. A microscopic similarity to the primitive synovium was observed early in the literature, but its histogenesis is still unclear $[6,14]$. Nevertheless, the term synovial sarcoma continues to be used. A 2010 study suggested that a human multipotent mesenchymal stem cell may be the cell of origin [15].

Histologically, there are three variants of synovial sarcoma [16]: monophasic, biphasic, and poorly differentiated. The monophasic variant is characterized by fascicles of atypical spindled cells with scant cytoplasm and monotonous vesicular nuclei, often overlapping. There is a variable mitotic rate. Collagenous stroma can be more or less abundant, and thickened bundles of "wiry 


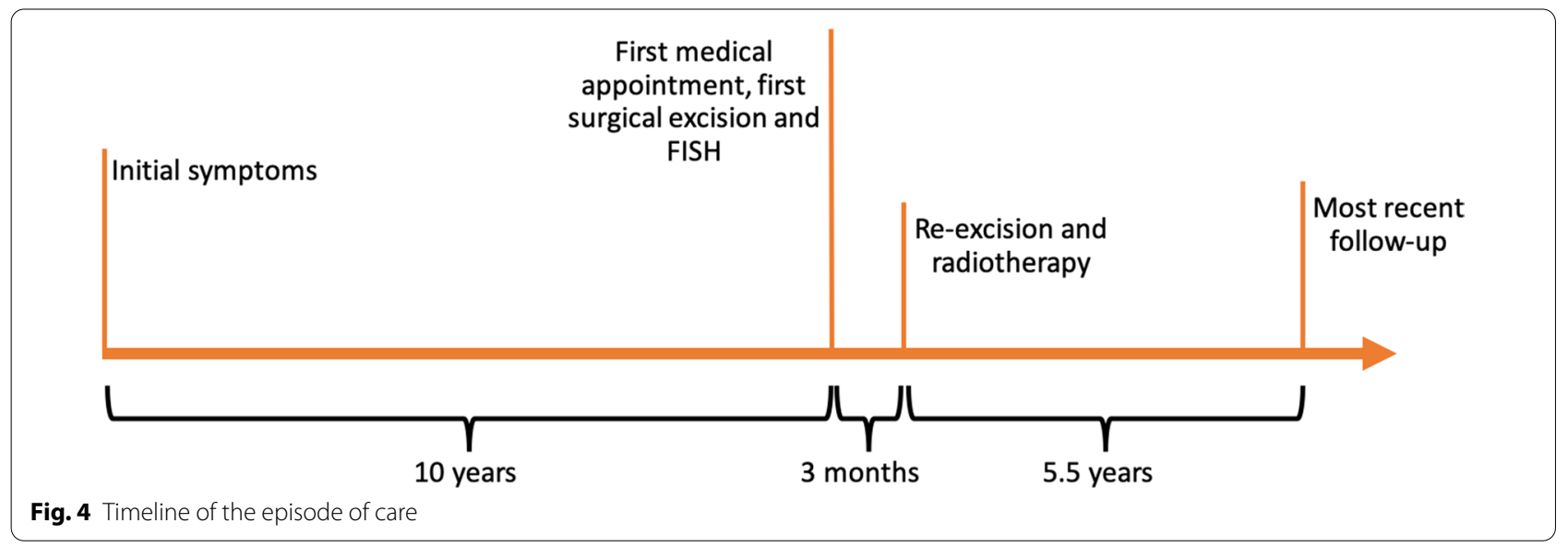

collagen" can be seen. Vasculature can be prominent, and hyalinization or myxoid changes are rarely seen. Mast cells are frequently observed, and necrosis is uncommon. Biphasic synovial sarcoma contains the aforementioned spindle cells, and in addition there is an epithelial component showing glandular or nested growth. The epithelial cells have amphophilic cytoplasm and round to ovoid nuclei. The glandular lumina may contain eosinophilic amorphous material or mucin. Rarely, squamous metaplasia can be seen. Poorly differentiated synovial sarcoma is characterized by hypercellularity, hyperchromatic nuclei, polymorphism, and increased mitoses. Necrosis is common. Poorly differentiated areas may be present adjacent to more typical monophasic or biphasic areas. In some cases, the entire tumor is poorly differentiated.

A characteristic cytogenetic translocation $t(X ; 18)$ (p11.2;q11.2) is present in almost all synovial sarcomas; helping provide diagnostic confirmation. This translocation fuses SS18 (SYT) in chromosome 18 and SSX1, SSX2, or SSX4 in chromosome X [17]. Immunohistochemistry shows that synovial sarcomas are strongly positive for TLE1, although other sarcomas and carcinomas can rarely express TLE-1 $[18,19]$. Keratins and EMA are diffusely positive in the epithelial components, and focally positive in the spindled cells [20]. Focal S100 protein or SOX10 positivity can also be seen in a percentage of cases. CD56 and CD99 are usually positive, while CD34, SMA, desmin, myogenin, PAX3, synaptophysin, TTF-1, and NKX2 are negative [21].

In 1986, Dreyfuss et al. [11] performed a literature review of hand synovial sarcoma cases occurring between 1934 and 1984. An English literature search in PubMed using the terms "synovial sarcoma", "hand" and "wrist" from 1983 to 2020 was performed to provide a review of cases not included in the aforementioned review. Our literature search started from 1983 in order to include a paper from 1983 (Kinsella et al. [22]), which was not reported in Dreyfuss's review. One hundred and eightynine cases of synovial sarcoma of the hand-wrist have been recorded $[6,8,10,12,13,22-67]$ during the past 37 years (Table 1). Among these, 57 cases in the hand-wrist where demographic, pathologic, and clinical information was available were analyzed (Table 2).

The demographic features of the cases reported in the literature are summarized in Table 3 . The male-tofemale ratio was $1.23: 1$, which is slightly diminished compared to Dreyfuss's ratio (1.68:1). The mean age of the present literature review (33.6 years) is similar to that from Dreyfuss's study (33 years). Thirty-seven subjects $(65 \%)$ were between 10 and 40 years old, and only $5(8.7 \%)$ were above 69 years old. These results are in accordance with the findings of Dreyfuss $e t a l$. and in keeping with the literature [16]. Therefore, these findings corroborate that the case report presented herein is a rare occurrence.

The hand was the most commonly involved location (45 cases, 78\%). Nearly all cases involved the soft tissue with the palmar surface of the hand reported in 18 cases, the dorsal surface in four, the area between metacarpals in five, the fingers in eight, the anatomical snuffbox in one. A digital nerve was involved in one case, while an unspecified hand area was reported in eight cases. The wrist was involved in 14 cases $(24.5 \%)$, and two cases concomitantly involved the hand. Among these, in 13 cases affected the soft tissue, while only one case involved the median nerve. These findings confirm that the incidence of finger involvement by this type of sarcoma is less common than that of the carpus [13].

In 20 cases collected, the duration of symptoms before diagnosis was clearly stated in the studies and is reported in Table 3. In six cases, the tumors were initially considered benign conditions, like abscesses, fibromas, arthritis, and so forth. According to most authors, a delay in diagnosing this kind of tumor is very 
Table 1 Summary of the Pub-Med English literature on 189 cases of synovial sarcoma of hand-wrist (19832020)

\begin{tabular}{|c|c|c|}
\hline Author & Year & $\begin{array}{l}\text { \# of hand- } \\
\text { wrist cases }\end{array}$ \\
\hline Kinsella & 1983 & 1 \\
\hline Adeyemi-Doro & 1985 & 1 \\
\hline Louis & 1986 & 1 \\
\hline Tsujimoto & 1987 & 2 \\
\hline Swift & 1990 & 1 \\
\hline O'Leary & 1991 & 1 \\
\hline Weiss & 1992 & 1 \\
\hline Milanov & 1993 & 2 \\
\hline Fleegler & 1994 & 2 \\
\hline Brien & 1995 & 8 \\
\hline Kransdorf & 1995 & 51 \\
\hline O'Connell & 1996 & 1 \\
\hline Gross & 1997 & 1 \\
\hline Nakajima & 1997 & 1 \\
\hline Chesser & 1999 & 1 \\
\hline Harjai & 1999 & 1 \\
\hline McPhee & 1999 & 2 \\
\hline Takhtani & 1999 & 1 \\
\hline Wong & 2001 & 2 \\
\hline Egger & 2002 & 1 \\
\hline Imaizumi & 2002 & 1 \\
\hline Kawai & 2002 & 3 \\
\hline Chew & 2005 & 12 \\
\hline Buecker & 2006 & 21 \\
\hline Michal & 2006 & 13 \\
\hline Muramatsu & 2008 & 1 \\
\hline Pradhan & 2008 & 10 \\
\hline Talbot & 2008 & 6 \\
\hline Bar & 2009 & 2 \\
\hline Gilleard & 2009 & 1 \\
\hline Puhaindran & 2010 & 2 \\
\hline Singh & 2011 & 1 \\
\hline Steinstraesser & 2011 & 1 \\
\hline Casal & 2012 & 1 \\
\hline Muramatsu & 2013 & 1 \\
\hline Kim & 2014 & 1 \\
\hline Maia & 2014 & 1 \\
\hline Outani & 2014 & 5 \\
\hline Puhaindran & 2014 & 1 \\
\hline Omori & 2015 & 1 \\
\hline Ward & 2015 & 1 \\
\hline Damato & 2017 & 1 \\
\hline Houdek & 2017 & 8 \\
\hline Sahoo & 2017 & 1 \\
\hline Aiba & 2018 & 4 \\
\hline Cavit & 2018 & 1 \\
\hline Dean & 2018 & 2 \\
\hline
\end{tabular}

Table 1 (continued)

\begin{tabular}{lcc}
\hline Author & Year & $\begin{array}{c}\text { \# of hand- } \\
\text { wrist cases }\end{array}$ \\
\hline Fujibuchi & 2019 & 1 \\
Karki & 2019 & 1 \\
Ohan & 2020 & 1 \\
Stacy & 2020 & 1 \\
Total & & 189 \\
\hline
\end{tabular}

frequent due to the insidious growth pattern and nonspecific radiological appearance. These tumors can be present for extended periods (2-20 years). In the case report herein described, the patient presented with a slowly growing hand-wrist mass, which became progressively more painful over a 10 -year period.

The greatest dimensions of the tumors at diagnosis were clearly reported in only 34 cases. Size ranged between 0.5 and $10 \mathrm{~cm}$, with an average of $2.8 \mathrm{~cm}$. In eight additional cases, the size reported was " $5 \mathrm{~cm}$ or less", while in two it was "more than $5 \mathrm{~cm}$ ". In total, 37 cases out of 44 were diagnosed when the tumor size was $5 \mathrm{~cm}$ or less. Therefore, this review and the presented case report show that in a majority of cases, this tumor is $5 \mathrm{~cm}$ or less in greatest dimension. This is in disagreement with few articles stating that larger tumor sizes are usually present at diagnosis [13]. The rates of different histologic subtypes are reported in Table 3.

Radical surgical excision was the treatment of choice (57 cases, 100\%). Adjuvant radiotherapy was performed in 29 cases (51\%), while chemotherapy was used in 12 cases (21\%), either before or after surgery. These percentages are higher than those observed by Dreyfuss et al., who found that $30 \%$ of patients had radiotherapy and $5 \%$ chemotherapy. This demonstrates more widespread use of therapies like radiation and chemotherapy in recent decades to treat synovial sarcomas.

The follow-up period is summarized in Table 3. The recurrence rate was $32.6 \%$ (16 out of 49 followedup cases): in 4 cases local recurrences were seen, in 9 cases lung metastases, in one case lymph node metastasis, and in 4 the site of recurrence was not specified. According to the literature, the rate of recurrence of these tumors is around 80\% [60]. In Dreyfuss at al. review, the rate of recurrence was $54 \%$. Several factors have been associated with a higher recurrence risk: advanced age, larger tumor size $(>5 \mathrm{~cm})$, central location, male sex, neurovascular or bone invasion, p53 overexpression, high proliferative index, specific SYTSSX fusion types, and incomplete excision [68, 69]. Regarding the excision of hand-wrist tumors, it has to be considered that these body areas present particular challenges due to their specific anatomic features: 


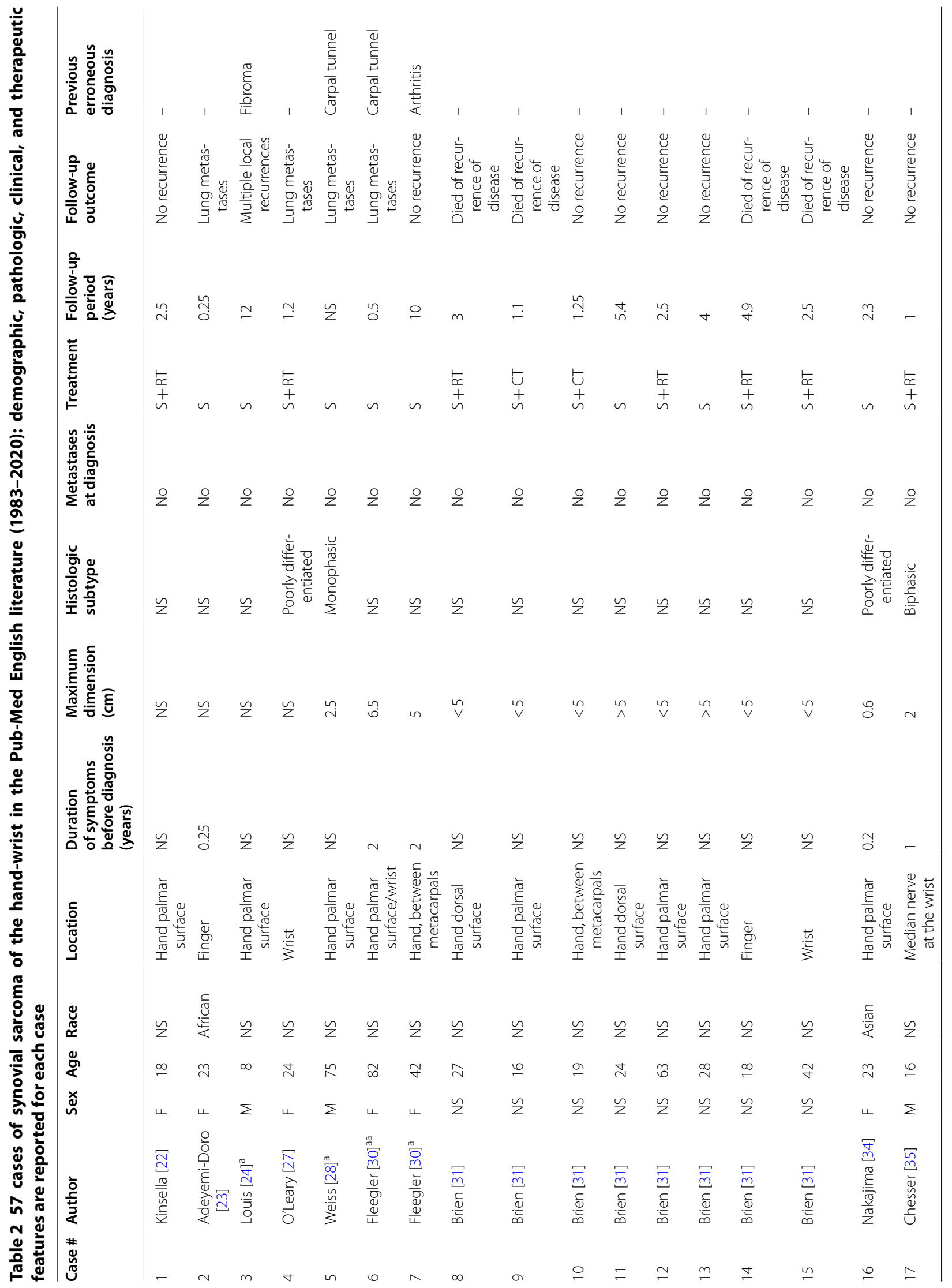




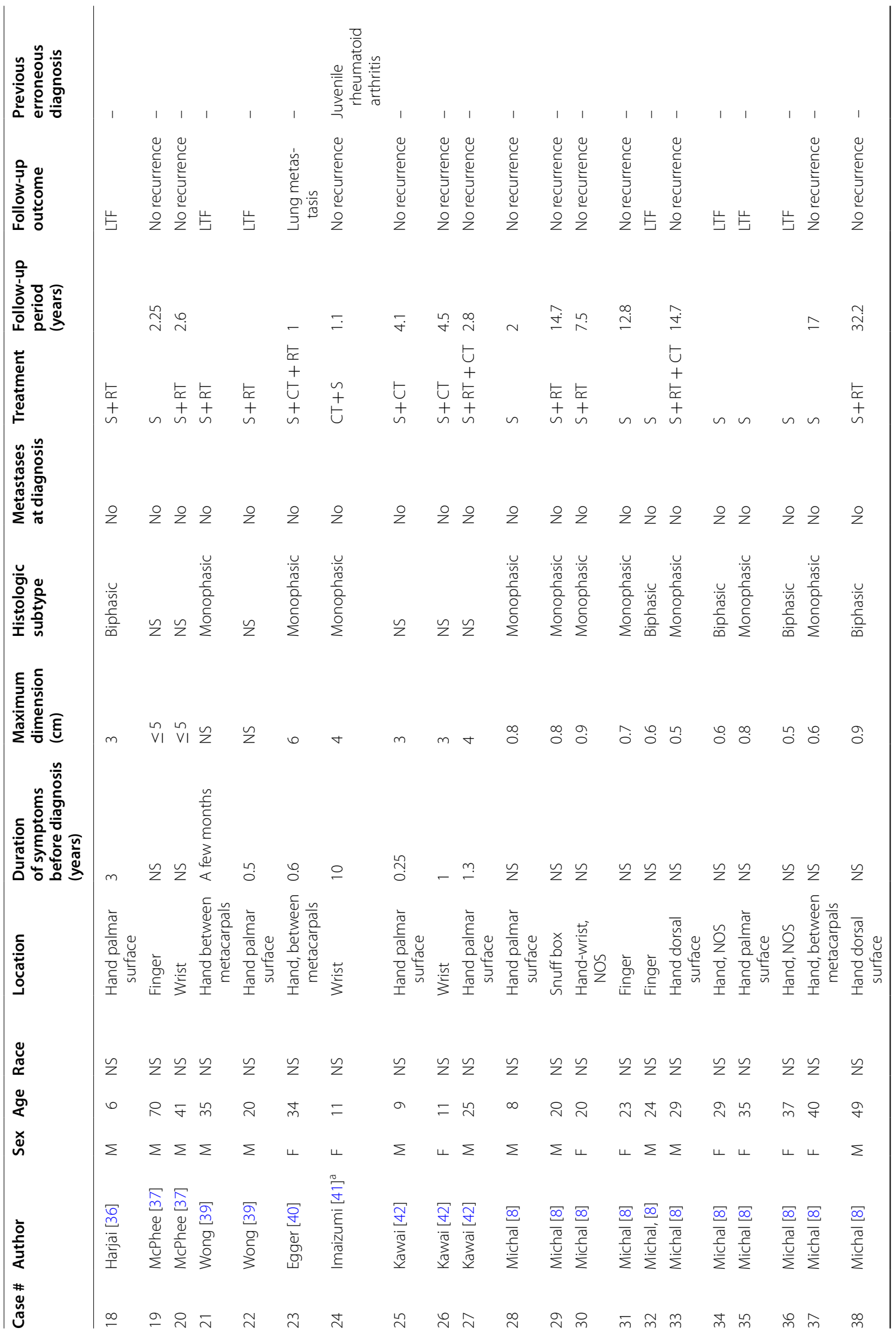




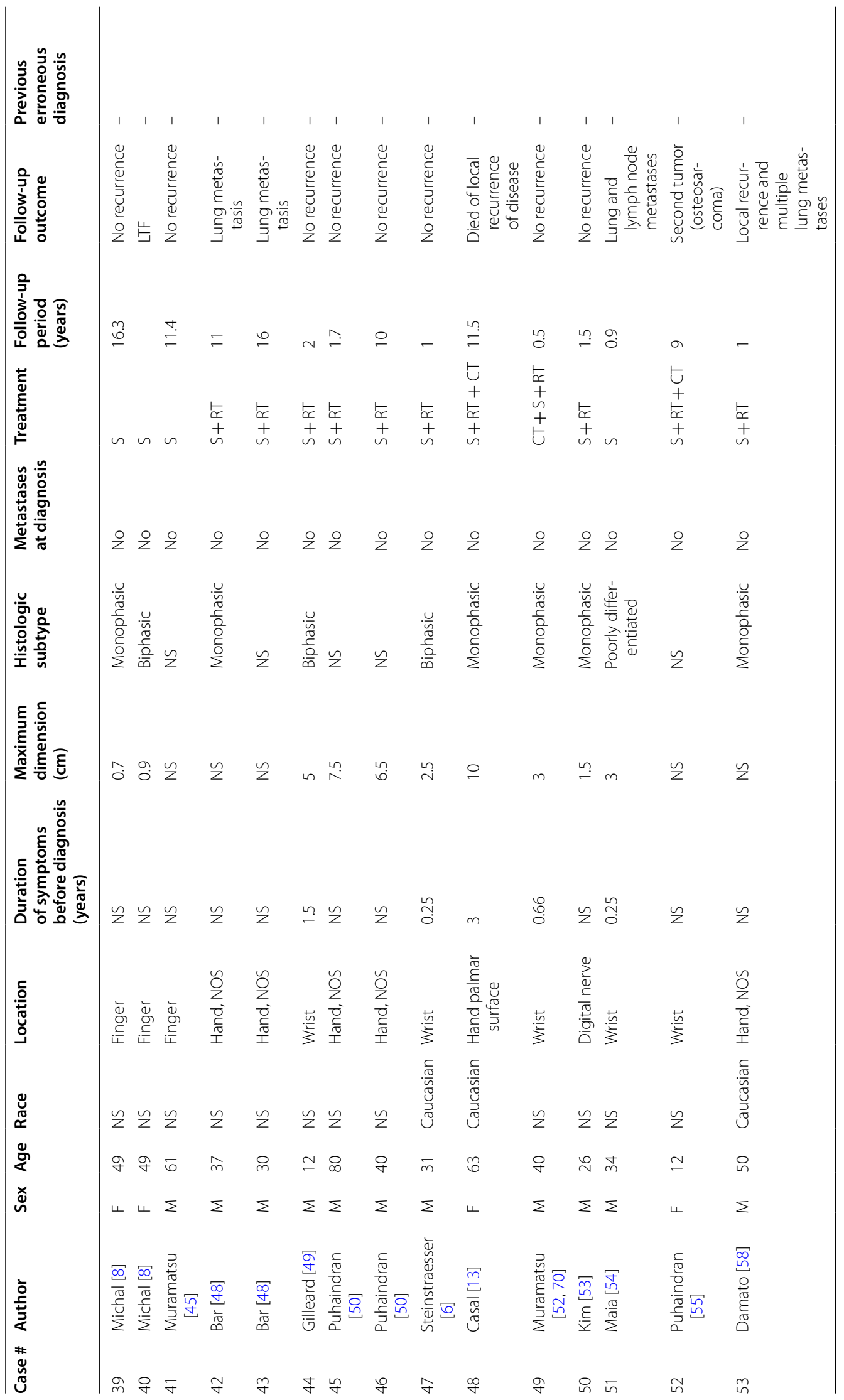




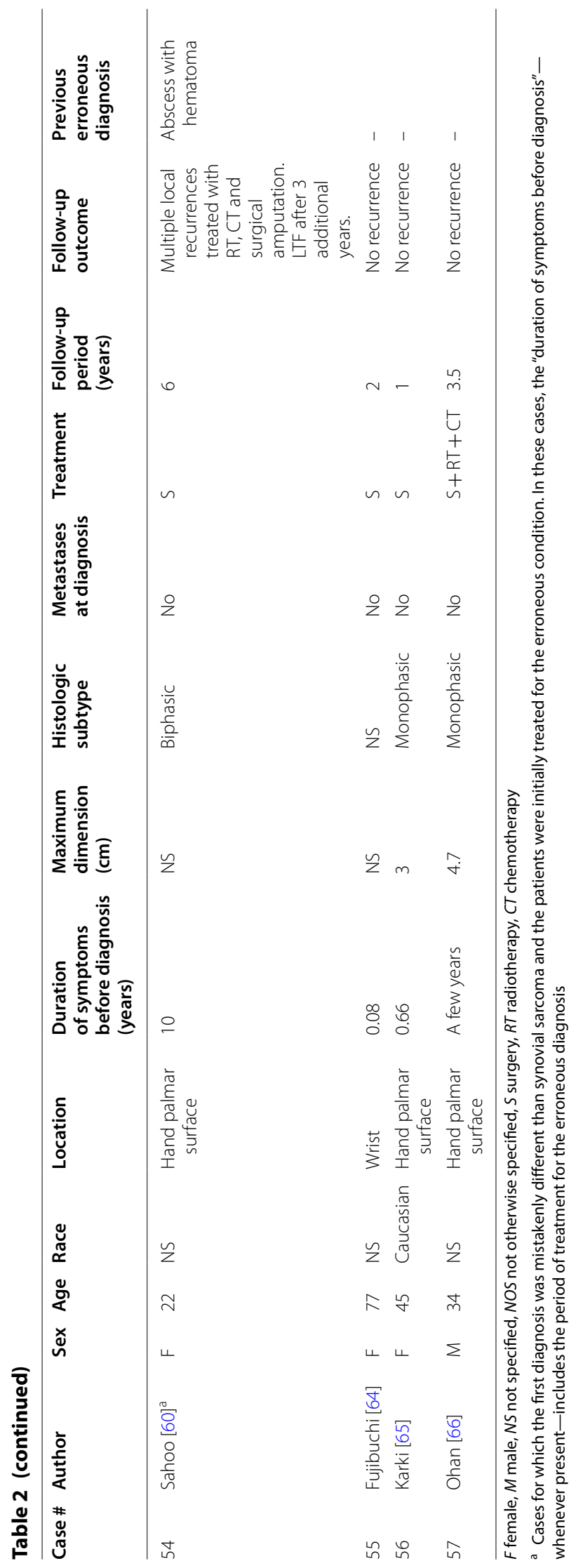


Table 3 Summary of demographic, histologic and clinical parameters for the 57 subjects analyzed. For each parameter, $\mathbf{N}$ highlights the number of subjects for whom the parameter was provided

\begin{tabular}{|c|c|}
\hline Parameter & \\
\hline \multicolumn{2}{|l|}{ Sex } \\
\hline $\mathrm{N}$ & 49 \\
\hline Males & $27(55 \%)$ \\
\hline Females & $22(45 \%)$ \\
\hline \multicolumn{2}{|l|}{ Race } \\
\hline $\mathrm{N}$ & 6 \\
\hline African & 1 \\
\hline Caucasian & 4 \\
\hline Asian & 1 \\
\hline \multicolumn{2}{|l|}{ Age } \\
\hline $\mathrm{N}$ & 57 \\
\hline Mean & 33.6 \\
\hline Median & 29 \\
\hline Min, $\max$ & 6,82 years \\
\hline \multicolumn{2}{|l|}{ Histology subtype } \\
\hline $\mathrm{N}$ & 32 \\
\hline Monophasic & $19(59 \%)$ \\
\hline Biphasic & $10(31 \%)$ \\
\hline Poorly differentiated & $3(10 \%)$ \\
\hline \multicolumn{2}{|c|}{ Duration of symptoms before diagnosis } \\
\hline $\mathrm{N}$ & 20 \\
\hline Mean & 2 years \\
\hline Min, $\max$ & $0.08,10$ years \\
\hline \multicolumn{2}{|l|}{ Follow-up period } \\
\hline $\mathrm{N}$ & 49 \\
\hline Mean & 5.8 years \\
\hline Min, max & $0.25,32.2$ years \\
\hline
\end{tabular}

there is limited soft tissue, and each compartment is small. Therefore, it can be difficult to obtain wide surgical margins [70]. In the present literature review, chi-square analysis was used to compare the rate of recurrence and metastasis in different subgroups of patients. The rate of recurrence and metastasis was not significantly different $(p>0.05)$ when comparing tumor size (less than or equal to $5 \mathrm{~cm}$ versus those greater than $5 \mathrm{~cm}$ ), histology subtype (biphasic versus monophasic), and age (those less than or equal to 40 versus those older than 40). It is uncertain why the recurrence rate in the present literature review is relatively lower compared to the review by Dreyfuss et al. and also considering that Dreyfuss did not provide the tumors' size at diagnosis in their analysis.

In the literature analyzed, the mortality rate was $10.2 \%$ (5 out of the 49 followed-up subjects). Sixteen patients (28\%) survived at least 5 years after beginning treatment. Twelve (21\%) survived at least 10 years, with one surviving more than 32 years. The overall fiveyear survival rate for synovial sarcomas of any location is $27-85 \%$ in the literature $[13,16]$. Dreyfuss et al. in their review focused on hand synovial sarcomas found that $18 \%$ of the patients survived five years after beginning treatment and 9\% survived ten years. Therefore, the present literature review showed an improved 5 -year and 10-year survival in hand-wrist sarcomas in the recent decades. Various factors seem to have a poor survival prognostic value in subjects affected by synovial sarcomas [71]: advanced age at diagnosis, tumors larger than 4 or $5 \mathrm{~cm}$, central location, poorly differentiated histology. Recent data suggest that fusion type does not have survival prognostic value. The synovial sarcoma in the case report herein described had several favorable prognostic factors that could justify the uneventful five-years follow-up: peripheral location, small size, lack of poorly differentiated histology, negative resection margins at the re-excision.

In conclusion, this literature review confirms that synovial sarcomas of hand-wrist are more frequent among males and subjects 10 to 40 years old. These findings corroborate that the case report presented is a rare occurrence. In the literature analyzed, the incidence of finger involvement by this type of sarcoma was less common than that of the remaining areas of the hand and wrist. A delay in diagnosis was not common, probably because a high level of suspicion for this tumor has been achieved. Moreover, in most cases, this tumor was diagnosed when $5 \mathrm{~cm}$ or less in greatest dimension. The five-year survival rate in the cases analyzed was higher than that reported in the previous literature review on hand synovial sarcomas; suggesting an improved survival in the recent decades.

\section{Abbreviations}

FISH: Fluorescence in situ hybridization.; CT: Computed tomography.; AJCC: American Joint Commission on Cancer.

\section{Acknowledgements}

Not applicable.

\section{Authors' contributions}

SS collected and interpreted the patient and literature data and wrote the manuscript. DZ performed histological and statistical analyses. DZ and LG were contributors in writing the manuscript. All authors read and approved the final manuscript.

\section{Funding}

This research received no specific grant from any funding agency in the public, commercial, or not-for-profit sectors.

Availability of data and materials

All data generated or analyzed during this study are included in this published article. 


\section{Ethics approval and consent to participate}

Submission to our institutional review board (SUNY Upstate Medical University IRB) was not required based on the content of the case report.

\section{Consent for publication}

Written informed consent was obtained from the patient for publication of this case report and any accompanying images. A copy of the written consent is available for review by the Editor-in-Chief of this journal.

\section{Competing interests}

The authors declare that they have no competing interests.

Received: 7 September 2020 Accepted: 30 November 2020

Published online: 17 January 2021

\section{References}

1. Siegel HJ, Sessions W, Casillas MA Jr, Said-Al-Naief N, Lander PH, LopezBen R. Synovial sarcoma: clinicopathologic features, treatment, and prognosis. Orthopedics. 2007;30(12):1020-7.

2. National Cancer Center, Synovial sarcoma. https://www.cancer.gov/pedia tric-adult-rare-tumor/rare-tumors/rare-soft-tissue-tumors/synovial-sarco ma. Accessed 7 Oct 2020.

3. Sultan I, Rodriguez-Galindo C, Saab R, Yasir S, Casanova M, Ferrari A. Comparing children and adults with synovial sarcoma in the Surveillance, Epidemiology, and End Results program, 1983 to 2005: an analysis of 1268 patients. Cancer. 2009;115:3537-47.

4. Athanasian EA. Bone and soft tissue tumors. In: Wolfe SW, Hotchkiss RN, Pederson WC, Kozin SH, editors. Green's Operative Surgery, vol. 2. Philadelphia: Churchill Livingstone; 2011. p. 2141-91.

5. Weitz J, Antonescu CR, Brennan MF. Localized extremity soft tissue sarcoma: improved knowledge with unchanged survival over time. J Clin Oncol. 2003;21(14):2719-25

6. Steinstraesser L, Agarwal R, Stricker I, Steinau HU, Al-Benna S. Biphasic synovial sarcoma of the extremity: quadruple approach of isolated limb perfusion, surgical ablation, adipofascial perforator flap and radiation to avoid amputation. Case Rep Oncol. 2011;4(1):222-8.

7. De Silva MV, Barrett A, Reid R. Premonitory pain preceding swelling: a distinctive clinical presentation of synovial sarcoma which may prompt early detection. Sarcoma. 2003;7(3-4):131-5.

8. Michal M, Fanburg-Smith JC, Lasota J, Fetsch JF, Lichy J, Miettinen M. Minute synovial sarcomas of the hands and feet: a clinicopathologic study of 21 tumors less than $1 \mathrm{~cm}$. Am J Surg Pathol. 2006;30(6):721-6.

9. Nicholson S, Milner RH, Ragbir M. Soft tissue sarcoma of the hand and wrist: epidemiology and management challenges. J Hand Microsurg. 2018;10(2):86-92

10. Outani H, Hamada K, Oshima K, et al. Clinical outcomes for patients with synovial sarcoma of the hand. Springerplus. 2014;3(649):1-5.

11. Dreyfuss UY, Boome RS, Kranold DH. Synovial sarcoma of the hand-a literature study. J Hand Surg Br. 1986;11(3):471-4.

12. Kransdorf MJ. Malignant soft-tissue tumors in a large referral population: distribution of diagnoses by age, sex, and location. AJR Am J Roentgenol. 1995;164(1):129-34

13. Casal D, Ribeiro Al, Mafra M, et al. A 63-year-old woman presenting with a synovial sarcoma of the hand: a case report. J Med Case Rep. 2012;6(385):1-7.

14. Ferrari A, Gronchi A, Casanova M, et al. Synovial sarcoma: A retrospective analysis of 271 patients of all ages treated at a single institution. Cancer. 2004:101:627-34

15. Naka N, Takenaka S, Araki N, et al. Synovial sarcoma is a stem cell malignancy. Stem Cells. 2010;28(7):1119-31.

16. Lindberg MR. Diagnostic pathology. Soft tissue tumors. 2nd ed. Amsterdam: Elsevier; 2016. p. 659-62

17. Nakano K, Takahashi S. Translocation-related sarcomas. Int J Mol Sci. 2018;19(12):1-19.

18. Zaccarini DJ, Deng X, Tull J, Maciak C, Valente AL, Zhang S. Expression of TLE-1 and CD99 in carcinoma: pitfalls in diagnosis of synovial sarcoma. Appl Immunohistochem Mol Morphol. 2018;26(6):368-73.
19. Foo WC, Cruise MW, Wick MR, Hornick JL. Immunohistochemical staining for TLE1 distinguishes synovial sarcoma from histologic mimics. Am J Clin Pathol. 2011:135(6):839-44.

20. Miettinen M, Limon J, Niezabitowski A, Lasota J. Patterns of keratin polypeptides in 110 biphasic, monophasic, and poorly differentiated synovial sarcomas. Virchows Arch. 2000;437(3):275-83.

21. Lindberg MR, Synovial sarcoma. https://app.expertpath.com/document/ synovial-sarcoma/1fd6f3b6-8060-4634-960b-07093cdb7364?searchTerm =synovial\%20sarcoma. Accessed 8 Jan 2020.

22. Kinsella TJ, Loeffler JS, Fraass BA, Tepper J. Extremity preservation by combined modality therapy in sarcomas of the hand and foot: an analysis of local control, disease free survival and functional result. Int J Radiat Onco Biol Phys. 1983;9(8):1115-9.

23. Adeyemi-Doro HO, Durosimi-Etti FA, Olude O. Primary malignant tumors of the hand. J Hand Surg Am. 1985;10(6 Pt 1):815-20.

24. Louis DS, Hankin FM, Hankin RC, Brennan M, Greene TL. Synovial cell sarcoma: a case report with a comment on 27 years of treatment. J Hand Surg Am. 1986:11(4):578-81.

25. Tsujimoto M, Ueda T, Nakashima H, Hamada H, Ishiguro S, Aozasa K. Monophasic and biphasic synovial sarcoma. An immunohistochemical study. Acta Pathol Jpn. 1987;37(4):597-604

26. Swift JE, Blend MJ, Bekerman C, Das Gupta TK, Greager JA. Detection of pulmonary metastases in a patient with synovial cell sarcoma using In-111 labeled monoclonal antibody 19-24. Clin Nucl Med. 1990;15(4):227-30.

27. O'Leary C, el Soussi M, Cowie J. Spontaneous bilateral pneumothoraces from synovial cell sarcoma. Respir Med. 1991:85(6):533-4.

28. Weiss AP, Steichen JB. Synovial sarcoma causing carpal tunnel syndrome. J Hand Surg Am. 1992;17(6):1024-5.

29. Milanov NO, Shilov BL, Tjulenev AV. Surgical treatment of radiation injuries of the hand. Plast Reconstr Surg. 1993:92(2):294-300.

30. Fleegler EJ. An approach to soft tissue sarcomas of the hand and upper limb. J Hand Surg Br. 1994;19(4):411-9.

31. Brien EW, Terek RM, Geer RJ, Caldwell G, Brennan MF, Healey JH. Treatment of soft-tissue sarcomas of the hand. J Bone Joint Surg Am. 1995:77(4):564-71.

32. O'Connell JX, Browne WL, Gropper PT, Berean KW. Intraneural biphasic synovial sarcoma: an alternative "glandular" tumor of peripheral nerve. Mod Pathol. 1996;9(7):738-41

33. Gross E, Rao BN, Pappo AS, et al. Soft tissue sarcoma of the hand in children: clinical outcome and management. J Pediatr Surg. 1997:32(5):698-702.

34. Nakajima H, Matsushita K, Shimizu H, et al. Synovial sarcoma of the hand. Skeletal Radiol. 1997;26(11):674-6.

35. Chesser TJ, Geraghty JM, Clarke AM. Intraneural synovial sarcoma of the median nerve. J Hand Surg Br. 1999:24(3):373-5.

36. Harjai MM, Bal RK, Nagpal BMVSM, Sadhotra LP, Maudar KK. Paediatric hand tumours-synovial sarcoma: a rare malignancy. Med J Armed Forces India. 1999:55(2):169-70.

37. McPhee M, McGrath BE, Zhang P, Driscoll D, Gibbs J, Peimer C. Soft tissue sarcoma of the hand. J Hand Surg Am. 1999:24(5):1001-7.

38. Takhtani D, Saleeb SF, Chalker TL. General case of the day Synovia sarcoma of the carpal tunnel (monophasic fibrous type). Radiographics. 1999;19(5):1394-6.

39. Wong $\mathrm{CH}$, Chow $\mathrm{L}$, Yen $\mathrm{CH}, \mathrm{Ho}$ PC, Yip R, Hung LK. Uncommon hand tumours. Hand Surg. 2001;6(1):67-80.

40. Egger JF, Coindre JM, Benhattar J, Coucke P, Guillou L. Radiation-associated synovial sarcoma: clinicopathologic and molecular analysis of two cases. Mod Pathol. 2002;15(9):998-1004.

41. Imaizumi S, Morita T, Kobayashi H, Ito T, Hirata Y. Synovial sarcoma with extended occult period treated as juvenile rheumatoid arthritis: a case report. J Orthop Sci. 2002;7(5):570-3.

42. Kawai A, Hasizume H, Sugihara S, Morimoto $Y$, Inoue $H$. Treatment of bone and soft tissue sarcomas of the hand and wrist. Int Orthop. 2002;26(1):26-30

43. Chew FS. Radiology of the hands: review and self-assessment module. Am J Roentgenol. 2005;184(6 Suppl):S157-68.

44. Buecker PJ, Villafuerte JE, Hornicek FJ, Gebhardt MC, Mankin HJ. Improved survival for sarcomas of the wrist and hand. J Hand Surg Am. 2006;31(3):452-5. 
45. Muramatsu K, Ihara K, Doi K, Hashimoto T, Seto S, Taguchi T. Primary reconstruction with digital ray transposition after resection of malignant tumor. Arch Orthop Trauma Surg. 2008;128(10):1017-21.

46. Pradhan A, Cheung YC, Grimer RJ, et al. Soft-tissue sarcomas of the hand: oncological outcome and prognostic factors. J Bone Joint Surg Br. 2008;90(2):209-14.

47. Talbot SG, Mehrara BJ, Disa JJ, et al. Soft-tissue coverage of the hand following sarcoma resection. Plast Reconstr Surg. 2008;121(2):534-43.

48. Bar I, Papiashvilli M. Two cases of an enormous single-lung metastasis from synovial sarcoma. Ann Thorac Surg. 2009;88(5):1697-8.

49. Gilleard O, Stone C, Devaraj V. Synovial sarcoma within the carpal tunnel of a child: sentinel lymph node biopsy and microvascular reconstruction. J Hand Surg Eur. 2009;34(3):405-6.

50. Puhaindran ME, Steensma MR, Athanasian EA. Partial hand preservation for large soft tissue sarcomas of the hand. J Hand Surg Am. 2010;35(2):291-5

51. Singh A, Kate MP, Nair MD, Kesavadas C, Kapilamoorthy TR. Bilateral perisylvian infarct: a rare cause and a rare occurrence. Singapore Med J. 2011;52(4):e62-5.

52. Muramatsu K, Moriya A, Miyoshi T, Tominaga Y, Seto S, Taguchi T. Vascularized sural nerve graft and extracorporeally irradiated osteochondral autograft for oncological reconstruction of wrist sarcoma: case report and review of literature. Ann Plast Surg. 2013;71(5):544-6.

53. Kim JH, Lee HJ, Han I, Ha JH, Baek GH. Intraneural synovial sarcoma of the digital nerve in a hand: a case report and review of the literature. JBJS Case Connect. 2014;4(2):e40-6.

54. Maia DC, Menezes CK, Bastos TC, Ferreira LC, Francesconi F. Poorly differentiated synovial sarcoma in the wrist-case report. An Bras Dermatol. 2014;89(5):816-8.

55. Puhaindran ME, Hamilton K, Schlumbohm S, Rich M, Mitchell D, Steensma M. Radiation-induced osteosarcoma of the hand: case report. J Hand Surg Am. 2014;39(6):1151-4.

56. Omori S, Hamada K, Outani H, et al. Intraoperative extracorporeal autogenous irradiated tendon grafts for functional limb salvage surgery of soft tissue sarcomas of the wrist and hand. World J Surg Oncol. 2015;13(179):1-6.

57. Ward IM, Scott JN, Mansfield LT, Battafarano DF. Dual-energy computed tomography demonstrating destructive calcium pyrophosphate deposition disease of the distal radioulnar joint mimicking tophaceous gout. J Clin Rheumatol. 2015:21(6):314-7.

58. Damato A, Larocca M, Rondini E, Menga M, Pinto C, Versari A. Severe rhabdomyolysis during treatment with trabectedin in combination with a herbal drug in a patient with metastatic synovial sarcoma: a case report [published correction appears in Case Rep Oncol. 2017 May 23;10 (2):455]. Case Rep Oncol. 2017;10(1):258-64.

59. Houdek MT, Walczak BE, Wilke BK, Kakar S, Rose PS, Shin AY. What factors influence the outcome of surgically treated soft tissue sarcomas of the hand and wrist? Hand. 2017;12(5):493-500.

60. Sahoo TK, Dhal I, Das SK, Majumdar SKD, Parida DK. Synovial sarcoma of palmar aspect of hand and survival: a rare case report. J Clin Diagn Res. 2017;11(7):XD9-11.

61. Aiba H, Yamada S, Mizutani J, et al. Preoperative evaluation of the efficacy of radio-hyperthermo-chemotherapy for soft tissue sarcoma in a case series. PLoS ONE. 2018;13(4):e0195289.

62. Cavit A, Özcanli H, Sançmiş M, Ocak GA, Gürer El. Tumorous conditions of the hand: a retrospective review of 402 cases. Turk Patoloji Derg. 2018;34(1):66-72.

63. Dean BJF, Branford-White $H$, Giele H, et al. Management and outcome of acral soft-tissue sarcomas. Bone Joint J. 2018;100-B(11):1518-23.

64. Fujibuchi T, Miyawaki J, Kidani T, et al. Intraosseous synovial sarcoma of the distal ulna: a case report and review of the literature. BMC Cancer. 2019;19(1):1-7.

65. Karki D, Dash S, Muthukumar V. Synovial sarcoma of palm masquerading as a neural tumor: a challenging differential diagnosis. Int J Appl Basic Med Res. 2019;9(3):176-8.

66. Ohan H, Minassian G, Samra AH, Zdilla MJ. Synovial sarcoma of the hand. Case Rep Pathol. 2020;2020:8491864.

67. Stacy GS, Bonham J, Chang A, Thomas S. Soft-tissue tumors of the handimaging features. Can Assoc Radiol J. 2020;71(2):161-73.

68. Wolden SL, Alektiar KM. Sarcomas across the age spectrum. Semin Radiat Oncol. 2010;20:45-51.

69. Eilber FC, Dry SM. Diagnosis and management of synovial sarcoma. J Surg Oncol. 2008;97:314-20.

70. Muramatsu K, Ihara K, Yoshida K, Tominaga Y, Hashimoto T, Taguchi T. Musculoskeletal sarcomas in the forearm and hand: standard treatment and microsurgical reconstruction for limb salvage. Anticancer Res. 2013;33(10):4175-82

71. El Beaino M, Araujo DM, Lazar AJ, Lin PP. Synovial sarcoma: advances in diagnosis and treatment identification of new biologic targets to improve multimodal therapy. Ann Surg Oncol. 2017;24(8):2145-54.

\section{Publisher's Note}

Springer Nature remains neutral with regard to jurisdictional claims in published maps and institutional affiliations.
Ready to submit your research? Choose BMC and benefit from:

- fast, convenient online submission

- thorough peer review by experienced researchers in your field

- rapid publication on acceptance

- support for research data, including large and complex data types

- gold Open Access which fosters wider collaboration and increased citations

- maximum visibility for your research: over 100M website views per year

At BMC, research is always in progress.

Learn more biomedcentral.com/submissions 